Special Issue "Recent Developments in International Money and Finance" Editor: Ronald MacDonald

\title{
Is Old Money Better than New? Duration and Monetary Regimes
}

\author{
Ilian Mihov \\ INSEAD, Singapore \\ Andrew K. Rose \\ Haas School of Business, University of California
}

\begin{abstract}
:
We compare the duration and performance of different monetary regimes, especially the contrast between countries those that fix exchange rates and those that target inflation. Inflation targeting is a more durable policy; no country has yet been forced to abandon an inflation target, while many have abandoned fixed exchange rates. Indeed, even though inflation targeting began only in 1990, the duration of inflation targeting regimes is at least as long as, or longer than all alternative monetary regimes for comparable countries. Regime duration also matters in monetary policy; older regimes are typically more successful than younger ones in achieving low inflation.
\end{abstract}

JEL: E52, E58

Keywords: Empirical; panel; exchange; rate; inflation; policy; data; success; target; filter; time

Correspondence: Ilian Mihov, Shell Fellow and Professor of Economics and Area Coordinator, Economic and Political Sciences, INSEAD and CEPR Research Fellow; ilian.mihov@insead.edu. Andrew K. Rose, Rocca Professor of International Business, NBER Research Associate and CEPR Research Fellow; arose@haas.berkeley.edu.

Andrew K. Rose thanks the National University of Singapore and the Monetary Authority of Singapore for hospitality while this paper was written. Both authors thank two anonymous referees for comments. 


\section{$1 \quad$ Monetary Policy and the Filter of Time}

Old things often tend to be better than new. After all, they have to be better, simply to survive. Think of cars, literature, buildings ... and perhaps monetary policies as well. In this paper, we ask two related questions: a) does durability vary systematically across different monetary regimes? and $b$ ) does regime durability matter? The answer to both questions is positive. Regimes that last longer tend to deliver better results, and not all monetary regimes are equally likely to survive. Our particular focus is inflation targeting (hereafter "IT"), a monetary regime first introduced by New Zealand in 1990. Even though IT is still a relatively young framework, it has already proven itself to be more durable than alternative monetary regimes; we are especially interested in comparing IT to well-defined alternatives such as fixed exchange rates. And this durability matters; older regimes are more likely to deliver good inflation outcomes than newer regimes. Succinctly, time is a good filter for monetary regimes, and inflation targeting has thus far shown itself to be the regime most likely to pass the test of time.

\section{Brief Literature Review}

We begin with a brief review of the relevant parts of the literature. There are three areas of research which are closely related to ours. They concern: a) the performance of IT; b) the duration of fixed exchange rate regimes; and c) taxonomies of monetary regimes. Readers in a hurry can skip this section without serious loss.

We are interested in comparing the durability and consequences of IT with that of other monetary regimes. There is already a large literature on inflation targeting, a monetary regime which has been analyzed extensively in both theory and practice (we define IT more precisely below). Among the many references are: Bernanke and Mishkin (1997), Svensson (1999), Mishkin and Schmidt-Hebbel (2001), and Roger and Stone (2005). Of particular relevance to us is a strand of the literature that compares the inflation performance of countries that formally practice IT with that of comparable countries that do not. Among the many papers in the latter area are: Ball and Sheridan (2004), Vega and Winkelried (2005), and Dueker and Fischer (2006). Such work often finds little difference in inflation between countries with and without IT. Still, little of this work is focused on regime durability. One of the most striking features of inflation targeting is that no country has ever left the regime in crisis. This durability stands in stark contrast to other monetary regimes, and is one of the chief motivations for this paper. ${ }^{1}$

Another literature analyzes the duration of exchange rate regimes; it is primarily focused on how and why fixed exchange rates fail during currency crises. This research obviously tackles the issue of regime durability directly. Work in this vein includes Klein and Marion (1997) and Wälti (2005), both papers that examine the longevity and

\footnotetext{
1 Another problem that dilutes the relevance of some of this work is that inflation targeters are usually compared to a group of countries with a range of heterogeneous monetary strategies.
} 
collapse of fixed exchange rates using standard statistical techniques developed primarily for epidemiology. ${ }^{2}$ Of even more direct interest is Husain et al (2005), who look at the characteristics and impact of exchange rate regime durability on monetary outcomes. These papers focus entirely on the operation of fixed exchange rates; no other monetary regimes are considered. While interesting, work that focuses on exchange rate policy exclusively does not map precisely onto monetary policy. While a fixed exchange rate is a clear constraint on monetary policy, a floating exchange rate is not a well-defined policy as it does not specify what the monetary authority actually does. When a fixed exchange rate is abandoned, the monetary authority has to choose another monetary regime, and the thrust of this paper is to argue that not all regimes are created equally.

In recognition of this issue, researchers have begun to create taxonomies of monetary regimes that go above and beyond simply exchange rate policy. References in this vein include: Cottarelli and Giannini (1997) and Stone and Bhundia (2004); see also Mishkin (1998) and Dehejia and Rowe (2000). The research in this area tends to be descriptive, with little analysis of any sort, let along of regime duration or its consequences. In any case, most work in the area is more narrowly focused on differentiating between exchange rate policy stances; see e.g., Reinhart and Rogoff (2004), hereafter "RR," Levy-Yeyati and Sturzenegger (2005), hereafter "LYS," and Bubula and Ötker-Robe (2002), hereafter "BOR." All three of these well-known papers classify countries as belonging to different exchange rate regimes at different periods of time on the basis of actual policy. While of obvious relevance to us, much of this research is of only limited appeal since it often does not clearly specify the objective(s) of monetary policy.

The closest paper to ours is Roger and Stone (2005), who also focus on the durability of IT regimes. They attribute the resiliency of the regime to its flexibility, high standards of transparency and accountability, and the lack of any realistic alternative. Still, while this and much of the literature is of relevance to us, it does not do precisely what we are interested in. We are primarily interested in using durability as a measure of success in comparing different types of monetary regimes; we are especially interested in comparing inflation targeting to other well-defined monetary policies such as fixed exchange rates (money growth targets, and currency board would be others). We now turn to that task.

\section{$3 \quad$ Who Targets Inflation?}

Our primary interest is comparing IT to other monetary regimes. Accordingly, it is appropriate to first list countries that actually target inflation. We use the five criteria suggested by Mishkin (2004) to classify a country as targeting inflation: a) the public announcement of medium-term numerical targets for inflation, b) an institutional commitment to price stability as the primary goal of monetary policy, c) an informationinclusive strategy to set policy instruments, d) increased transparency of the monetary

2 An older strain of work that analyzes currency crises using event-study techniques is of less relevance to us. 
policy strategy, and e) increased accountability of central bank for attaining its inflation objectives. $^{3}$

Table 1 is taken from Rose (2006) and tabulates the countries that were formally targeting inflation as of the end of 2006. As we are particularly interested in regime duration, a default date is listed for the date when the country began IT. Since there is some dispute about the precise date when a country began to target inflation, we also list a "conservative" date that is often later; details are provided in Rose (2006).

The most striking feature of Table 1 is implicit in the column at the right, which lists dates when countries stopped targeting inflation. Finland and Spain are the only countries ever to have left IT; both joined EMU in January 1999, and neither left IT under economic duress. As we shall show, this durability is a strong contrast to the usual switches experienced by other monetary regimes.

Table 1: Inflation Targeting Countries

\begin{tabular}{|c|c|c|c|}
\hline & Default Start Date & Conservative Start Date & Exit Date \\
\hline Australia & March, 1993 & September, 1994 & \\
\hline Brazil & June, 1999 & June, 1999 & \\
\hline Canada & February, 1991 & January, 1992 & \\
\hline Chile & January, 1991 & August, 1999 & \\
\hline Colombia & September, 1999 & October, 1999 & \\
\hline Czech Republic & January, 1998 & January, 1998 & \\
\hline Finland & February, 1993 & January, 1994 & January, 1999 (to EMU) \\
\hline Hungary & June, 2001 & August, 2001 & \\
\hline Iceland & March, 2001 & March, 2001 & \\
\hline Indonesia & July, 2005 & July, 2005 & \\
\hline Israel & January, 1992 & June, 1997 & \\
\hline Korea & April, 1998 & April, 1998 & \\
\hline Mexico & January, 1999 & January, 2001 & \\
\hline New Zealand & March, 1990 & March, 1990 & \\
\hline Norway & March, 2001 & March, 2001 & \\
\hline Peru & January, 2002 & January, 2002 & \\
\hline Philippines & January, 2002 & January, 2002 & \\
\hline Poland & September, 1998 & September, 1998 & \\
\hline Romania & August, 2005 & August, 2005 & \\
\hline Slovak Republic & January, 2005 & January, 2005 & \\
\hline South Africa & February, 2000 & February, 2000 & \\
\hline Spain & January, 1995 & January, 1995 & January, 1999 (to EMU) \\
\hline Sweden & January, 1993 & January, 1995 & \\
\hline Switzerland & January, 2000 & January, 2000 & \\
\hline Thailand & May, 2000 & May, 2000 & \\
\hline Turkey & January, 2006 & January, 2006 & \\
\hline United Kingdom & October, 1992 & October, 1992 & \\
\hline
\end{tabular}

\footnotetext{
3 Note that the monetary authority need not be independent from the government by these criteria, though
} in practice almost all IT countries have given their central banks instrument independence 


\section{The Comparison Group}

Inflation Targeting is an important policy, and its adoption has not been random. To compare IT countries with others sensibly, we restrict our attention to a "default sample" of countries that satisfy five criteria. First, the population has to be at least three million, which was the size of New Zealand in 1974. ${ }^{4}$ Second, the country has to have real GDP per capita of at least $\$ 2,000$ (using the PWT6.2 series adjusted for purchasing power), the approximate income of both Colombia and Thailand at the time they adopted IT. The first two criteria ensure that members of the control group are at least as large and rich as (most) IT countries. Third, we restrict our attention to observations from 1974, the year following the final collapse of the post-war Bretton Woods/Smithsonian regime. This implies that a country included in the sample could, in principle, have experienced a monetary regime for a total of 32 years by the end of 2006 (twice as long as the oldest IT regime.) Fourth, we do not consider countries or territories in currency unions throughout the period (such as Panama or Puerto Rico). Finally, we require that the country have at least 16 useable observations (this corresponds to the length of half the total possible sample, as well as the duration of the longest IT regime). We are left with a default set of 43 countries; these are tabulated in Table 2.5

Table 2: Number of Regime Switches, Default Sample of Countries

\begin{tabular}{|l|c|c|c|c|c|}
\hline Regime & GGW & RR & LYS-5 & BOR & SB \\
Classification: & $\mathbf{1 9 7 4 - 9 9}$ & $\mathbf{1 9 7 4 - 2 0 0 1}$ & $\mathbf{1 9 7 4 - 2 0 0 4}$ & $\mathbf{1 9 9 0 - 2 0 0 3}$ & $\mathbf{1 9 9 0 - 2 0 0 5}$ \\
\hline Number of Regimes: & $\mathbf{1 5}$ & $\mathbf{1 5}$ & $\mathbf{5}$ & $\mathbf{1 3}$ & $\mathbf{8}$ \\
\hline Argentina & 6 & 7 & 10 & 3 & 2 \\
\hline Australia & 3 & 3 & 0 & 0 & 1 \\
\hline Austria & 4 & 3 & 3 & 1 & 1 \\
\hline Belgium & 2 & 1 & 6 & 1 & 1 \\
\hline Brazil & 10 & 8 & 16 & 5 & 2 \\
\hline Canada & 1 & 1 & 9 & 1 & 1 \\
\hline Chile & 6 & 10 & 6 & 2 & 2 \\
\hline Costa Rica & 5 & 6 & 11 & 4 & 3 \\
\hline Croatia & 0 & 1 & 8 & 3 & 2 \\
\hline Czech Rep. & 1 & 2 & 5 & 4 & 2 \\
\hline Denmark & 1 & 3 & 2 & 0 & 0 \\
\hline Finland & 5 & 5 & 0 & 3 & 2 \\
\hline France & 5 & 8 & 11 & 1 & 1 \\
\hline Germany & 2 & 4 & 1 & 1 & 1 \\
\hline Greece & 4 & 6 & 7 & 2 & 1 \\
\hline Hong Kong & 2 & 2 & 0 & 0 & 0 \\
\hline Hungary & 2 & 2 & 3 & 3 & 2 \\
\hline Ireland & 3 & 2 & 1 & 1 \\
\hline
\end{tabular}

\footnotetext{
4 We note in passing that the population of Iceland, which maintains IT, is only currently around 300,000.

5 It is worth noting that six IT countries are not in our default sample: Colombia; Iceland; Indonesia; Philippines; Romania; and Thailand. Since a number of these countries experienced monetary instability during the sample period, this means that our duration results are likely to be understated.
} 


\begin{tabular}{|c|c|c|c|c|c|}
\hline Israel & 4 & 8 & 14 & 2 & 1 \\
\hline Italy & 6 & 8 & 15 & 3 & 3 \\
\hline Japan & 2 & 4 & 0 & 0 & 0 \\
\hline Korea & 2 & 6 & 18 & 1 & 2 \\
\hline Lithuania & 1 & 1 & 2 & 2 & 1 \\
\hline Malaysia & 4 & 3 & 21 & 4 & 1 \\
\hline Mexico & 3 & 10 & 13 & 2 & 2 \\
\hline Netherlands & 2 & 4 & 12 & 1 & 1 \\
\hline New Zealand & 3 & 2 & 4 & 0 & 0 \\
\hline Norway & 4 & 4 & 1 & 4 & 2 \\
\hline Peru & 7 & 4 & 17 & 4 & 2 \\
\hline Poland & 1 & 5 & 1 & 3 & 2 \\
\hline Portugal & 5 & 5 & 9 & 2 & 1 \\
\hline Saudi Arabia & 0 & 1 & 2 & 0 & 0 \\
\hline Singapore & 3 & 2 & 11 & 3 & 0 \\
\hline Slovak Rep. & 2 & 3 & 8 & 2 & 1 \\
\hline South Africa & 2 & 3 & 10 & 3 & 2 \\
\hline Spain & 6 & 3 & 10 & 1 & 2 \\
\hline Sweden & 3 & 2 & 7 & 1 & 1 \\
\hline Switzerland & 1 & 2 & 16 & 0 & 1 \\
\hline Turkey & 4 & 7 & 10 & 4 & 1 \\
\hline USA & 1 & 3 & 0 & 0 & 1 \\
\hline UK & 3 & 3 & 1 & 1 & 1 \\
\hline Uruguay & 6 & 6 & 8 & 2 & 1 \\
\hline Venezuela & 5 & 5 & 15 & 5 & 3 \\
\hline
\end{tabular}

Numbers tabulated are switches of monetary regime during the sample period at top.

GGW: De jure exchange rate regimes from Ghosh, Gulde, and Wolf (2003). RR: De facto exchange rate regimes from Reinhart and Rogoff (2004). LYS-5: De facto exchange rate regimes from Levy-Yeyati and Sturzenegger (2005). BOR: De facto exchange rate regimes from Bubula and Otker-Robe (2002). SB: De facto monetary regimes from Stone and Bhundia (2004).

\section{Five Classifications of Monetary Regimes}

We are interested in comparing IT to other monetary regimes. This necessitates measuring the monetary regime of a country that is not targeting inflation. This is not an easy task, since there is no single way to classify monetary regimes that is generally accepted by the profession. Rather than developing our own measure of a country's monetary regime over time, we take advantage of taxonomies developed by others. We are aware of five such classifications; Table 2 presents information on them all. In particular, it tabulates the number of switches of monetary regime experienced during this sample for each of the countries in our default sample and for each of the five regime classifications.

What are these monetary taxonomies? First, we use the well-known system of Ghosh, Gulde, and Wolf (2003), hereafter "GGW". This classification assigns countryyear observations into one of fifteen exchange rate regime classifications on the basis of de jure exchange rate policy. Since declared policy often does not correspond to actual policy, the remaining four systems are de facto rather than de jure classifications. The first three of these cover only exchange rate regimes, and were created respectively by 
Reinhart and Rogoff (2004), hereafter "RR," Levy-Yeyati and Sturzenegger (2005), hereafter "LYS," and Bubula and Otker-Robe (2002), hereafter "BOR." RR create their data set by comparing exchange rate behavior for official and market rates to create a 15-way classification of exchange regimes. LYS use a combination of exchange rate behavior and central bank intervention to create a five-way classification of regimes (float, dirty float, crawling peg, fix, and inconclusive). ${ }^{6}$ The annual LYS data are available through 2004, while the monthly RR data extend only through 2001. BOR split their monthly data into 13 different exchange rate regimes; we use their year-end classifications for their data updated through the end of 2003. ${ }^{7}$ The remaining system is also only available since 1990 , but covers a broader range of monetary regimes than simply those of exchange rates. Stone and Bhundia (2004), hereafter "SB," split their sample into eight different kinds of monetary regimes, and we use their scheme updated through 2005.8

Obviously there are issues associated with these measures of monetary regimes. The samples, country coverage and frequencies do not coincide perfectly. None of the classifications cover the entire sample period, or all the countries. There are also differences in the classifications thrown out by the systems, which often disagree on a particular country-year observation. Accordingly, we consider all five systems to be imperfect and do not rely on any one exclusively.

\section{$4 \quad$ Does Durability Vary Across Monetary Regimes?}

The most striking feature of Table 2 is how many regime switches there have been during the sample period, no matter which classification system is used. It is little surprise that countries like Argentina and Brazil have been through numerous regimes. But multiple switches of the exchange rate regime show up even for low-inflation countries that are typically viewed as monetary bastions like Germany, Japan, and Switzerland. The exchange rate regimes presented in Table 2 seem less durable than the IT regimes of Table 1.

Figure 1 presents histograms of the duration of some especially interesting monetary regimes. We compare inflation targeters with fixed exchange rate regimes, since this is the most popular well-defined alternative monetary regime. Since fixes can be measured in different ways, we do not rely on any one method but instead portray three different schemes of pegged exchange rates (we use the expressions "pegs," "fixes," and so forth interchangeably). First, we classify a country as de jure pegged if it belongs to any of the seven relevant GGW bins, including: a) dollarized currencies; b) currency board arrangements; c) countries in monetary union; d) those pegged to single currency; e) published basket pegs; f) secret basket pegs; and g) cooperative pegs (such as the EMS). Second, we use RR and classify countries as having a de facto pegged exchange

\footnotetext{
6 LYS also create a 3-way scheme that we use below as well; it splits the observations into exchange rate regimes that are either fixed, intermediate, or floating.

7 Our thanks to Barry Eichengreen and Raul Razo-Garcia for the use of their updated BOR data set.

8 For more details on the individual classifications, the reader is referred to the original sources.
} 
Figure 1: Durations of Different Monetary Regimes, Default Sample

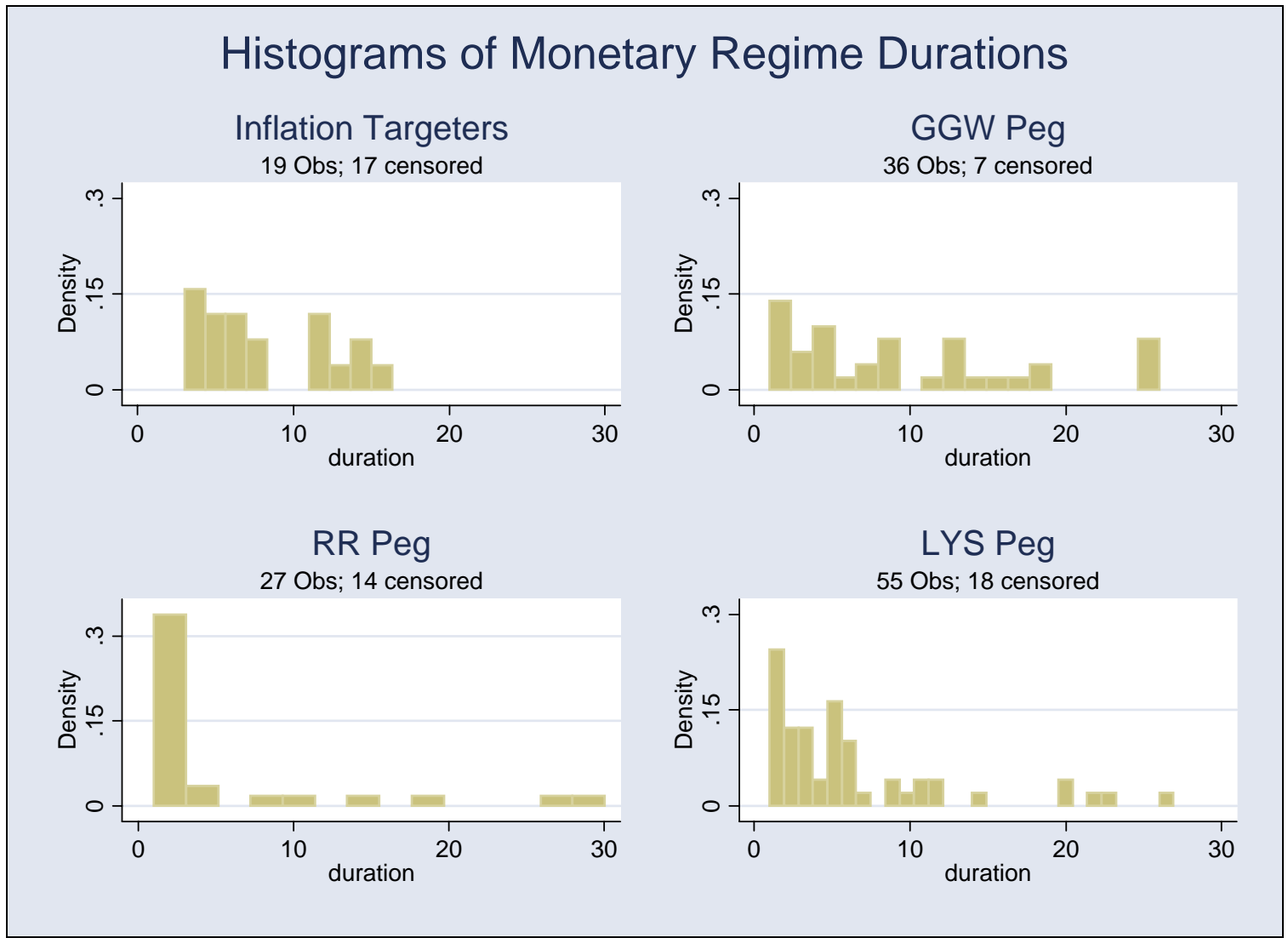

rate if it has any of a broad range of RR regimes including: a) no separate legal tender, b) pre-announced peg or currency board arrangements, c) pre-announced horizontal bands that are narrower than or equal to $+/-2 \%$, and d) de facto pegs. ${ }^{9}$ Finally, we also include fixed exchange regimes from the LYS 3-regime classification.

For the default sample, there are nineteen observations of inflation targeting regimes; the histogram of these is portrayed in the top-left graphic. While the period that we consider extends for over thirty years, IT has been around for only half of this time, so the histogram is necessarily skewed to the left. Still, the mass of the IT distribution is not particularly clustered at the extreme left of the histogram, unlike the three analogues for fixed exchange rates. The clustering towards the left in the latter reflects the fact that many fixed exchange rates survive only a short while. The more centered mass of the IT countries is especially striking when one notes that seventeen of the nineteen IT spells have been censored, in the sense that the countries were still in IT at the end of the sample. This censoring is more pronounced than that of any of the fixed exchange rate regimes, again reflecting the durability of IT compared with that of pegged exchange rates.

\section{A More Rigorous Approach}

Table 2 is descriptive, and shows widespread evidence of the instability of monetary regimes for a sample that is comparable to inflation targeters. Figure 1 provides

9 This corresponds to RR's gross code 1. 
corroborating evidence. However, neither provides a statistical test which rigorously compares the durability of IT regimes to monetary alternatives. Table 3 does precisely that. In particular, the duration of IT regimes is compared to each of a large number of relevant alternative monetary regimes using standard non-parametric techniques. ${ }^{10} \mathrm{We}$ use the two-sample Wilcoxon rank-sum (Mann-Whitney) test to compare the durations of monetary regime. This tests the hypothesis that two independent unmatched samples - for IT and one alternative monetary regime - are drawn from populations with the same distribution. In the column at the left, we present z-statistics for our default sample. A positive statistic indicates that IT durations are longer than those of the alternative monetary regime (tabulated at the extreme left of the table). One (two) asterisk(s) indicates that the difference in duration length is different at the $.05(.01)$ significance level. Thus the second statistic from the top indicates that monetary regimes classified by GGW as de jure currency boards have longer duration than IT regimes, though this difference is statistically insignificant at conventional levels. Each of the different rows of Table 3 compares the duration of IT to the duration of a different monetary regime; we consider all alternative regimes for the five classification schemes we consider (GGW, RR, LYS, BOR, and SB).

At the bottom of Table 3, we also compare our explicit inflation targeters to "implicit" inflation targeters. We define a country as an implicit inflation targeter if it has maintained inflation within a reasonable band for a large fraction of the last few years. Our default is to classify a country as an implicit inflation targeter if it kept annualized CPI inflation within a $(0,4 \%)$ band for at least $80 \%$ of the last 5 years of monthly observations. Clearly, these parameters are somewhat arbitrary, and we therefore pursue sensitivity analysis. We vary each of the three underlying parameters in our classification scheme sequentially by: a) requiring that inflation remain within the band for $90 \%$ instead of $80 \%$ of the last five years; b) using a $(1,3 \%)$ band instead of the broader $(0,4 \%)$ band; and c) using a four-year window instead of a five-year window. We thus arrive at four different ways to classify a country as an implicit inflation targeter.

The most striking feature of Table 3 is the number of positive and significant test statistics. Consider the default sample. Seven of the test statistics are significantly positive at the .01 level, and a further eight at the .05 level. It is true that most of the tests show results which are insignificantly different from zero; however, only five of the 23 negligible test-statistics are negative. Further, there are no significantly negative test-statistics; that is, there is no alternative monetary regime with reliably longer duration than inflation targeting. Succinctly, inflation targeting is not only $a$ durable monetary regime, it is the most durable monetary regime.

While the most important column of Table 3 uses our "default" sample, we also provide two robustness checks by presenting analogous figures for different samples. The "World" sample compares IT to all possible observations, while the column on the right-hand side compares the conservative dates for IT (presented in Table 1) to the default sample of observations. These robustness checks do not fundamentally change the underlying message from the default sample. ${ }^{11}$

\footnotetext{
10 We compare the IT durations to those of relevant alternatives, dropping regimes such as RR's "Freely Falling” or LYS's “intermediate.”

11 There are two exceptions: de jure currency boards and unions have significantly longer durability than inflation targeting when we consider all observations in the world. This is because small and/or poor
} 
Table 3 compares the duration of inflation targeting regimes with alternative monetary spells, such as fixed exchange rates. If a country moves in and out of a particular regime repeatedly, then a country can contribute a number of (necessarily short) spells to a particular alternative monetary regime. An alternative is to consider only the length of the final monetary regime, as is done in Table A1. This uses the Wilcoxon rank-sum tests of Table 3, but compares IT durations with the duration of only the last monetary regime. ${ }^{12}$ Again, the duration of inflation targeting regimes is significantly longer for the default sample than alternative exchange rate regimes proposed by GGW, RR, or BOR.

Table 3: Tests of Monetary Regime Duration: Inflation Targeting vs. Others

\begin{tabular}{|c|c|c|c|}
\hline Alternate Monetary Regime & $\begin{array}{l}\text { Default } \\
\text { Sample } \\
\end{array}$ & World & $\begin{array}{c}\text { Conservative } \\
\text { IT Dates } \\
\end{array}$ \\
\hline GGW: De Jure Dollarized & $\mathrm{n} / \mathrm{a}$ & -1.7 & $\mathrm{n} / \mathrm{a}$ \\
\hline GGW: De Jure Currency Board & -.8 & $-2.7 * *$ & -1.1 \\
\hline GGW: De Jure Monetary Union & $\mathrm{n} / \mathrm{a}$ & $-3.7 * *$ & $\mathrm{n} / \mathrm{a}$ \\
\hline GGW: De Jure Peg to 1 Currency & 1.4 & 1.8 & .8 \\
\hline GGW: De Jure Public Basket Peg & .1 & .2 & -.3 \\
\hline GGW: De Jure Secret Basket Peg & .6 & -.6 & .2 \\
\hline GGW: De Jure Coop Peg (EMS) & -.4 & -.9 & -.7 \\
\hline GGW: De Jure Crawling Peg & $2.0 *$ & $2.7 * *$ & 1.9 \\
\hline GGW: De Jure Target Zone & $2.8^{* *}$ & $3.1 * *$ & $2.7 * *$ \\
\hline RR: No sep legal tender & $4.6^{* *}$ & $2.1 *$ & $4.6^{* *}$ \\
\hline RR: Pre ann'd peg or CB & 1.0 & .5 & .4 \\
\hline RR: Pre ann'd narrow horizontal band & 1.7 & $2.2 *$ & 1.7 \\
\hline RR: De facto peg & 1.1 & $2.8 * *$ & .9 \\
\hline RR: Pre ann'd crawling peg & $2.6^{* *}$ & $2.0 *$ & $2.6^{* *}$ \\
\hline RR: Pre ann'd narrow crawling band & 1.8 & 1.9 & 1.5 \\
\hline RR: De facto crawling peg & .0 & 1.7 & -.3 \\
\hline RR: De facto crawling narrow band & .3 & 1.2 & -.2 \\
\hline RR: Pre ann'd crawling wide band & $2.3^{*}$ & $2.3 *$ & $2.3 *$ \\
\hline RR: De facto narrow crawling band & 1.0 & $2.2 *$ & .5 \\
\hline RR: Narrow Moving band & .5 & .8 & .2 \\
\hline LYS: Peg, 3-regime & $2.5^{*}$ & 1.2 & 1.9 \\
\hline LYS: Peg, 5-regime & $2.5^{*}$ & 1.2 & 1.9 \\
\hline BOR: No national legal tender & $\mathrm{n} / \mathrm{a}$ & .6 & $\mathrm{n} / \mathrm{a}$ \\
\hline BOR: Currency union & $3.3 * *$ & -1.1 & $2.8^{* *}$ \\
\hline BOR: Currency board & -1.1 & -1.8 & -1.5 \\
\hline BOR: Fixed & .2 & 1.9 & -.3 \\
\hline
\end{tabular}

countries are disproportionately likely to be in such regimes (at least before EMU began at the end of the sample). For instance, the de jure monetary unions consist mostly of countries in either Western/Central Africa or the Caribbean; see Rose (2000). As is well known from the literature on monetary unions, such regimes are highly durable. While interesting, this finding does not shake our basic confidence in the basic reliance of IT for countries of reasonable size and income.

12 It should be noted that the date of this final monetary regime differs by classification, since e.g., the GGW scheme is only available through 1999. 


\begin{tabular}{|l|c|c|c|}
\hline BOR: Composite fix & $2.2^{*}$ & 1.1 & $2.2^{*}$ \\
\hline BOR: Horizontal band & $2.4^{*}$ & $2.7^{* *}$ & $2.0^{*}$ \\
\hline BOR: Fwd-looking crawling & $2.1^{*}$ & $3.1^{* *}$ & $2.0^{*}$ \\
\hline BOR: Fwd-looking crawling band & 1.7 & $2.3^{*}$ & 1.1 \\
\hline BOR: Bkwd-looking crawling & $3.5^{* *}$ & $3.9^{* *}$ & $3.3^{* *}$ \\
\hline BOR: Bkwd-looking crawling band & 1.0 & $2.1^{*}$ & .8 \\
\hline SB: no Monetary Autonomy & .1 & -1.4 & -.8 \\
\hline SB: Fix & 1.2 & -.1 & .6 \\
\hline SB: Implicit Price Target & -.8 & -1.2 & -1.2 \\
\hline SB: Money Targeting & 1.3 & 1.4 & -1.9 \\
\hline CG: Money Targeting & -1.7 & -.4 & .8 \\
\hline Impl IT: Inflat in $(0,4) 80 \%$, last 5 yrs & $2.5^{*}$ & $2.4^{*}$ & $2.0^{*}$ \\
\hline Impl IT: Inflat in $(0,4) 90 \%$, last $5 \mathrm{yrs}$ & 1.2 & .7 & .6 \\
\hline Impl IT: Inflat in $(1,3) 80 \%$, last $5 \mathrm{yrs}$ & $4.1^{* *}$ & $4.3^{* *}$ & $3.9^{* *}$ \\
\hline Impl IT: Inflat in $(0,4) 80 \%$, last $4 \mathrm{yrs}$ & $3.5^{* *}$ & $3.7^{* *}$ & $2.0^{* *}$ \\
\hline
\end{tabular}

Statistics tabulated are z-statistics from two-sample Wilcoxon rank-sum (Mann-Whitney) tests comparing durations of Inflation Targeting with alternative monetary regime. Positive statistic indicates IT has longer duration than alternative. P-values less than .05 (.01) marked by one (two) asterisk(s).

GGW: De jure exchange rate regimes from Ghosh, Gulde, and Wolf (2003). RR: De facto exchange rate regimes from Reinhart and Rogoff (2004). LYS: De facto exchange rate regimes from Levy-Yeyati and Sturzenegger (2005). BOR: De facto exchange rate regimes from Bubula and Otker-Robe (2002). SB: De facto monetary regimes from Stone and Bhundia (2004). CG: Cottarelli and Giannini (1997). Impl IT: implicit inflation targeting.

Default sample: post- 1973 observations for countries with a) population $>3$ million, b) real PPP GDP $\mathrm{p} / \mathrm{c}$ $>\$ 2000$, c) national currencies, and d) at least 16 observations.

"World" denotes all available observations; "Conservative" uses conservative inflation targeting dates.

\section{$5 \quad$ Does the Durability of the Monetary Regime Matter?}

Having established that the durability of monetary regimes varies systematically and significantly, we now proceed to ask whether duration matters. We are particularly interested in asking whether older monetary regimes are more successful monetary regimes. We begin with a descriptive "event-study" approach before proceeding on to a more rigorous statistical approach.

\section{An Event Study}

Figure 2 is a set of event studies; each examines annual CPI inflation during the period after countries enter a particular monetary regime. The top-left graphic portrays inflation following the adoption of inflation targeting, while the other three graphics depict inflation after the adoption of fixed exchange rates. For each year after the adoption of a particular monetary regime, there is a distribution of inflationary outcomes. We portray both the central tendency and the dispersion of this distribution by graphing the $90^{\text {th }}$ - (upper) and $10^{\text {th }}$ - (lower) percentiles for inflation. ${ }^{13}$ Since

13 We do this rather than graphing means and standard deviations, because otherwise our fixed-exchange rate graphics are dominated by a few hyper-inflationary outcomes. 
Figure 2: Annual CPI Inflation after Regime Entry, Default Sample

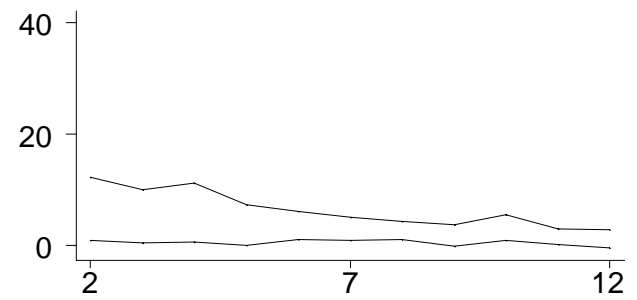

Inflation Targeters

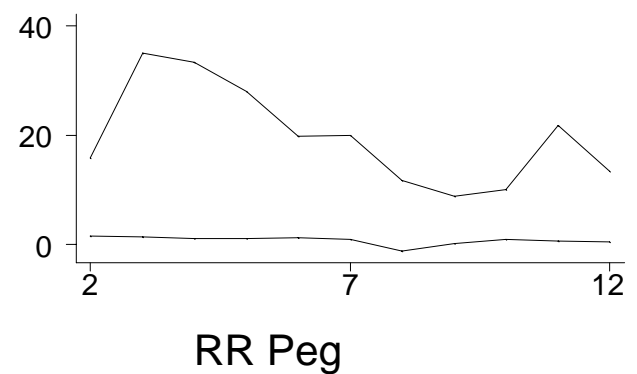

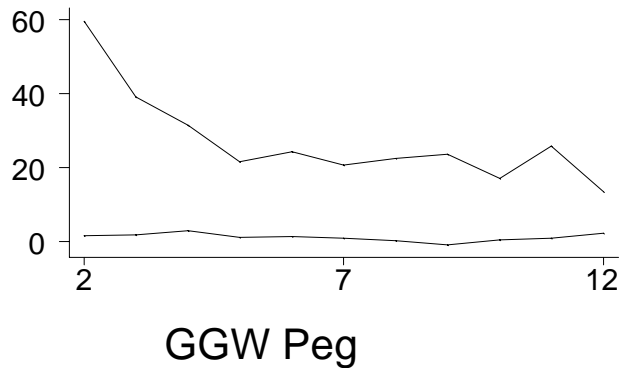

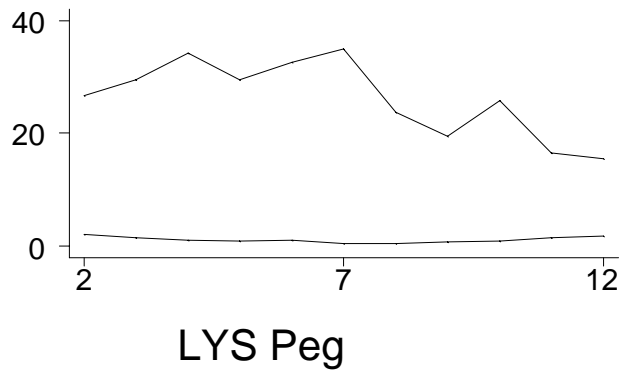

10\&90 Percentiles of Inflation Distribution

monetary regimes are often adopted as part of a disinflation program, we exclude the first two years following regime adoption, and portray data from the second through twelfth years after the adoption of a monetary regime. Besides inflation targeters, we use the three different schemes to classify fixed exchange rates of Figure 1.

Actual inflationary outcomes tend to be low and similar across countries for the twelve years after IT adoption. The cross-country dispersion of inflationary outcomes converges a little over the first few years, and after about five years inflation is low and similar across inflation targeters. The low cross-country dispersion of inflation under IT is in stark contrast to inflation following adoption of a fixed exchange rate. Some countries clearly achieve low inflation with a fixed exchange rate regime, but not all. No matter how one classifies fixed exchange rates, there is a great deal of cross-country variation in inflation performance following the adoption of a fixed exchange rate. This dispersion falls some but remains high for at least a decade after adoption of a peg.

The event-study suggests that IT delivers low and stable inflation, and that this tendency seems to grow stronger with time. Fixed exchange rates are also associated with low and stable inflation, though with much more variation. We now take a statistical approach, which enables us to analyze these issues more rigorously. Besides estimating the effect of duration on inflation quantitatively, we also take into account other factors that are omitted from the event-study analysis.

\section{Further Graphical Analysis}

In order to illustrate the link between durations and success in achieving low inflation graphically, in Figure 3 we report the evolution of success in achieving inflation between $0 \%$ and $4 \%$ for both inflation targeters and for countries with fixed exchange rates. The horizontal axis measures the duration of the regime, while the average 
success at achieving low inflation (for the countries that have adopted the regime) is portrayed on the vertical axis. Since we do not have multiple inflation targeting regimes that lasts more than fifteen years, we limit the span of all durations to fifteen years. For example, in our sample there are 19 countries that started an inflation targeting regime at some point in time. Out of these 19 countries only 6 achieved inflation within the $0 \%$ to $4 \%$ range in their first year of targeting. Hence the success rate after 1 year is $6 / 19$, or about $32 \%$.

There are several notable things about Figure 3. First, both inflation targeters and fixers see an almost monotonic increase in success rates. For inflation targeters it goes all the way up to $100 \%$, while for countries with fixed exchange rates it reaches almost $80 \%$ after 15 years. Second, inflation targeting dominates exchange rate fixes almost uniformly. In particular, there is a substantial difference in success rates for eight to twelve years after the regime starts. Most importantly, the results for exchange rate regimes have to be interpreted with caution because of survivorship bias. That is, the dashed line is based on exchange rate regimes that have survived. Naturally, we might expect that these are regimes where monetary conditions have been relatively stable. Since no inflation targeter has been forced to leave its IT under duress, we know that the IT data in the Figure is not driven by having only "good performers."

Figure 3: Success of IT and ERT Regimes in Achieving 0\% to 4\% Inflation (conditional on regime survival)

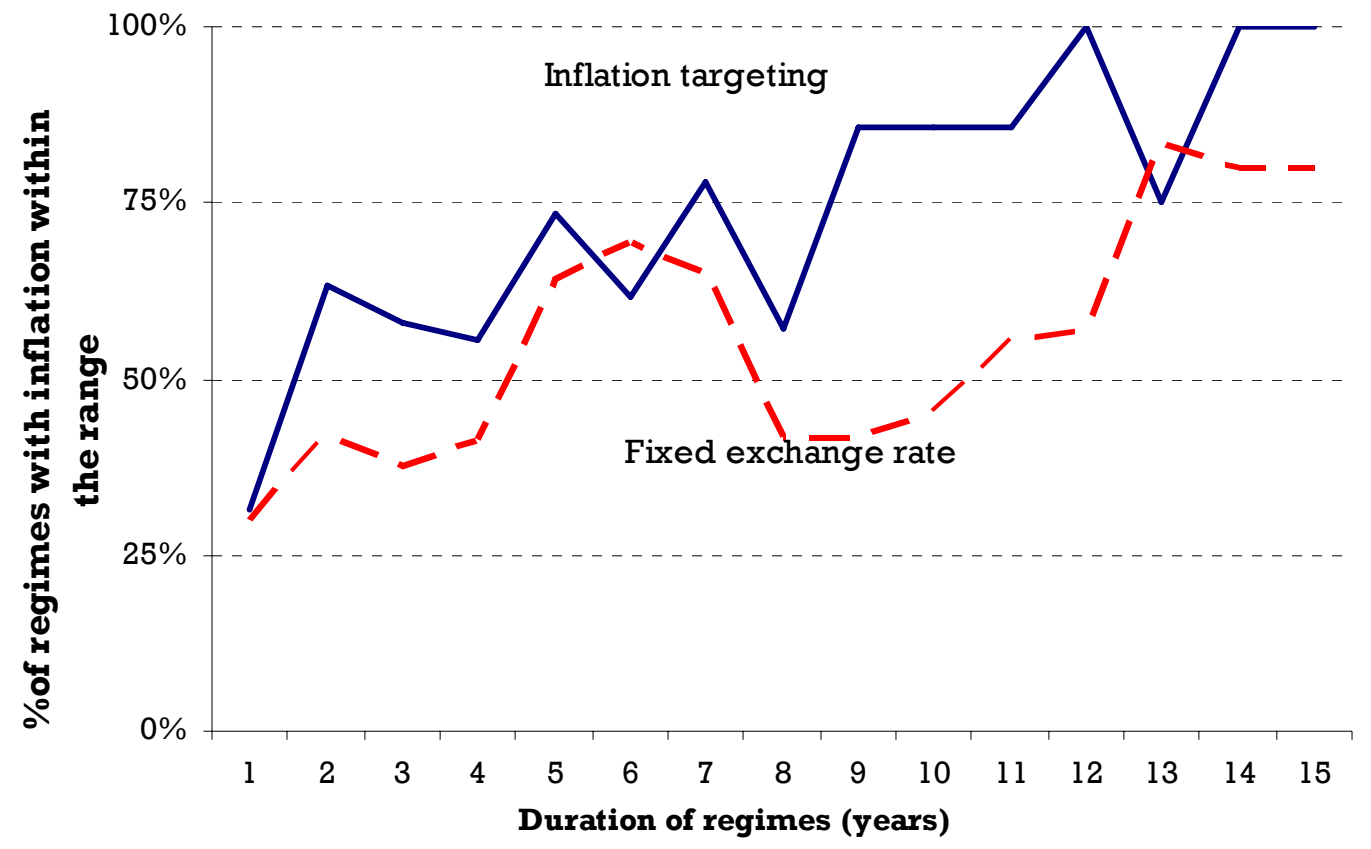

If we take survivorship bias for fixed exchange rate regimes into account, then the success rate for fixers should be adjusted downwards. One way to evaluate the importance of this bias is to track all fixers for fifteen years after the fix is introduced irrespective of whether the country continues to maintain a fixed exchange rate or not. The chart of Figure 4 presents the data. The inflation targeting data is unchanged from Figure 3, since none of the regime collapsed. For exchange rate targeters, the success rate is now very different. We have 98 regimes that were started at some point in our 
default sample and we trace all of these regimes for fifteen years after the initial adoption of the peg. There is some reduction in the number of observations which is due to the censoring that occurs in 2004 (though this censoring also applies for inflation targeters). As expected, time since the start of the regime matters for success but the effect is much less pronounced than the effect in Figure 3. Further, the difference between IT and fixed exchange rate regimes is quite pronounced. We can interpret Figure 3 as providing the success rate conditional on surviving, while Figure 4 provides the unconditional success rate. If we see a country adopting a fixed exchange rate and we do not know whether it will survive or not in the following few years, then Figure 4 provides a better estimate of the expected success rate in attaining low inflation.

The message from this analysis is clear. The longer the monetary regime, the more likely it is to have delivered good inflationary outcomes. But IT is associated with better monetary outcomes than a fixed exchange rate regime, especially if one takes into account the fact that many exchange rate fixes collapse.

\section{Regression Analysis}

Both inflation and its dispersion fall with duration, as observed in Figure 2. Further, longer regimes are more successful in achieving lower inflation, as shown in Figures 3 4. All this suggests, but does not definitively show, that duration matters for and inflation outcomes. To confirm this finding, we now analyze the link between regime durability and inflation performance using econometric techniques. As discussed above, a growing literature evaluates the effect of various regimes on macroeconomic performance. We depart from the standard methodology of the literature in two ways. First, we focus on regime duration; hence our key explanatory variable will be the spelllength of the specific monetary regime that a country is experiencing at a point in time. Second, our dependent variable is based on the success of achieving low and stable inflation. We define that to mean annual inflation falling within a tight, low range

Figure 4: Success of IT and ERT Regimes in Achieving 0\% to 4\% Inflation (irrespective of regime survival)

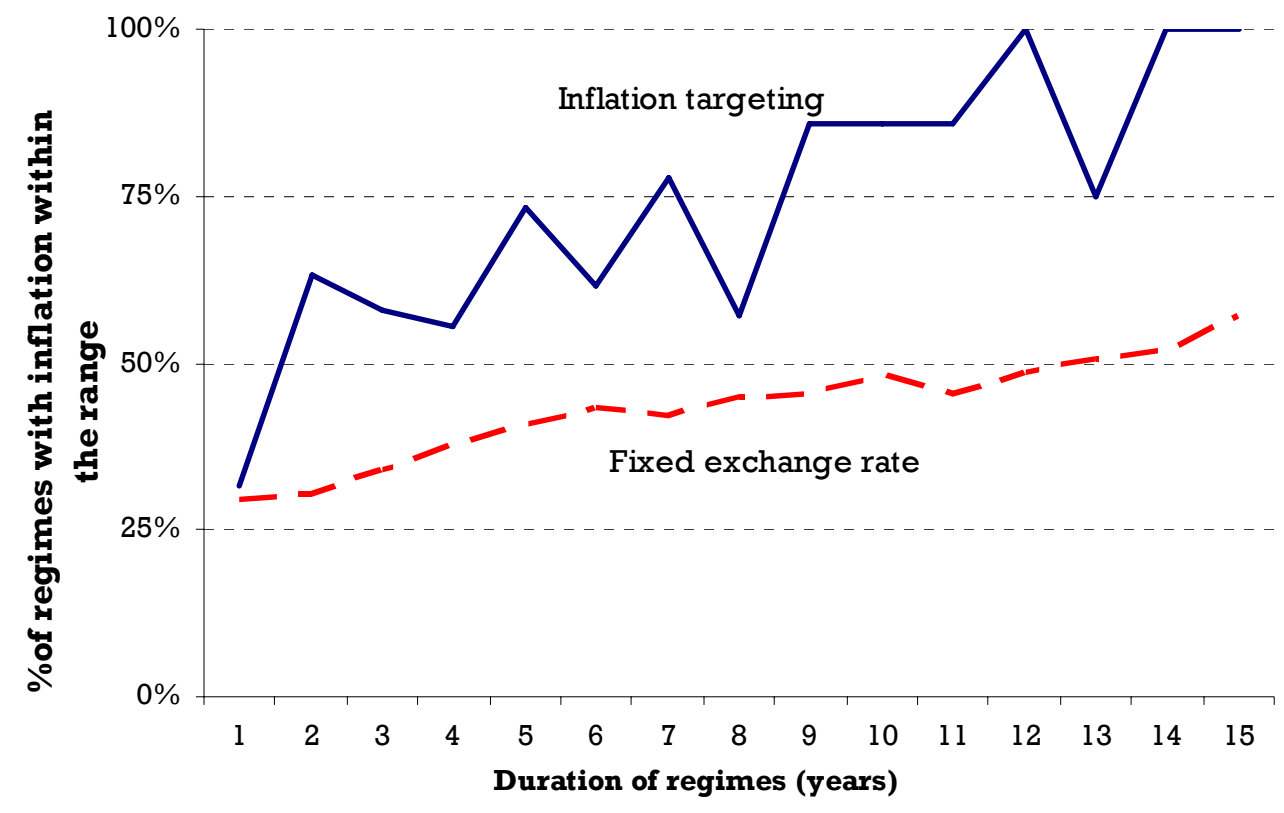


similar to that of relevance to most monetary authorities. Our default definition is that a country has achieved low inflation if its annual CPI inflation rate lies between $0 \%$ and $4 \%$ (though we redo everything for a more narrow range of $1 \%$ to $3 \%$ ). We interpret these ranges as being broadly consistent with what is usually referred to as "low inflation." We use a dummy variable approach, defining an inflationary outcome as "successful" (one) if inflation lies within the $(0,4 \%)$ range and "unsuccessful" (zero) otherwise. We do this to limit the influence of inflation outliers, and also because we want to construct measures of the cumulative success of a regime over time.

There are four monetary regimes that we consider in our analysis: inflation targeting, exchange rate fixes, money targeting, and regimes without any explicit quantitative goal. For each country we let the data set define the monetary regime and construct variables that capture the duration of the regime, as described in the previous section. Our sources for the default classification of regimes are the following: Inflation targeting is defined as in Table 1. As our default, we use the fixed exchange rate regimes provided by Levi-Yeyati and Sturzenegger (2005). Money targeting regimes are derived from Cottarelli and Giannini (1997) for the period before 1994. For the period 1995 - 1999, there is no uniform source of data and we use information collected from national central banks to determine whether the bank practices some form of money targeting. For the period after 2000, we use the IMF's Annual Report on Exchange Arrangements and Exchange Restrictions. ${ }^{14}$

Our first set of regressions is based on the following specification:

$$
\begin{aligned}
\mathrm{CS}_{\mathrm{it}}= & \alpha+\beta_{\mathrm{IT}} \mathrm{ITDur}_{\mathrm{it}}+\beta_{\mathrm{E}} \text { ERTDur }_{\mathrm{it}}+\beta_{\mathrm{M}} \text { MTDur }_{i \mathrm{it}}+\beta_{\mathrm{N}} \mathrm{NQGDur}_{\mathrm{it}} \\
& +\gamma^{\prime} \mathrm{X}_{\mathrm{it}}+\varepsilon_{\mathrm{it}}
\end{aligned}
$$

where:

- $C S_{i t}$ is the cumulative success in hitting the target range for country $\mathrm{i}$ at time $\mathrm{t}$. This variable represents accumulation of a binomial success variable and it is reset to zero with every regime change. To construct this variable we first construct for each country a binomial variable $S_{\text {it }}$ which is equal to 1 if country $i$ achieved inflation rate between $0 \%$ and $4 \%$ in year $t$. If the inflation rate was outside this range, then $S_{i t}$ is set to $0 . \mathrm{CS}_{\mathrm{it}}$ is then defined as: $\mathrm{CS}_{\mathrm{it}}=\sum_{\mathrm{s}=0}^{\tau_{\mathrm{it}}-1} \mathrm{~S}_{\mathrm{i}, \mathrm{t}-\mathrm{s}}$, where $\tau_{\mathrm{it}}$ is equal to the duration of the regime in country $i$ at time $t$.

- ITDur is the duration of the inflation targeting regime, if one exists

- ERTDur is the duration of the fixed exchange rate regime, if one exists, using LYS 3-way classification

\footnotetext{
14 In some cases, our indicators suggest that a country has both a fixed exchange rate regime and is an inflation target. We eliminate such inconsistencies by taking inflation targeting as a dominant regime and setting both the exchange rate fix dummy and the money targeting dummy to zero. We do this since it seems to accord with actual central bank practice; inflation targeters (like Chile and Israel) seem less concerned with their exchange rate than with inflation. Similarly, if a country is not an inflation targeter and there is a conflict between exchange rate targeting and money targeting, we take the exchange rate fix as the dominant regime and set the money targeting dummy to zero. If the central bank does not have an explicit target (inflation, exchange rate or money), then we code it as a country with no quantitative goal.
} 
- MTDur is the duration of the money targeting regime, if one exists

- NQGDur is the length of time that no explicit quantitative monetary target exists,

- $\quad \gamma$ is a set of nuisance coefficients

- $X$ is a vector of controls and/or fixed effects

- $\varepsilon$ is a well-behaved residual.

The coefficients of interest to us are $\{\beta\}$. We estimate this regression with least squares. Since our dependent variable is count data, it might be more appropriate to estimate the model by using Poisson or negative binomial regressions. Accordingly, we have estimated our equation with both Poisson and negative binomial techniques and found that our main conclusions still hold. For ease of interpretation, in the main text we report only the least squares results, but Poisson estimates are provided in Table A2 for the interested reader. ${ }^{15}$

Table 4 reports the results from a series of regressions based on our default equation. We begin at the extreme left with a column that represents the estimates for our default sample without any control variables. There are two results. First, each of the four coefficients for the monetary regimes is positive and significant; longer monetary regimes seem to raise the chances of good inflation outcomes. Second, the effect for inflation targeting is by far the largest of any of the four regimes. Succinctly, longer monetary regimes seem to be more successful at delivering low inflation, and IT is the most potent policy in the sense that it delivers the highest odds of success.

The rest of Table 4 is a set of sensitivity analyses to ensure that these results are robust and not the result of some unimportant or arbitrary feature of our methodology. Immediately to the right of the default results, we treat all four monetary regimes as having equal coefficients, collapsing the four duration variables into one. Thus, the second column at the left of the table provides an estimate of the effect of duration on monetary success for our default sample averaged across four regimes. Again, the effect is positive and significant; duration is associated with success. Our results are also basically unchanged when we consider data for the whole world as we report in the third column. The possibility that duration matters simply because of an omitted fixed country or time effect is addressed in the next two columns of the table. And although time effects reduce somewhat the magnitude of the duration effect, cumulative success increases with duration.

One potential issue with the regressions in the first four columns is that both durations and cumulative success are trending non-decreasing variables. Thus it is possible that the relationship between duration and success is spurious. The inclusion of time effects should address potential issues if there is a common trend, but not if there are individual stochastic trends in success rates and in durations. To address this issue we run the regression by including a lag of the dependent variable as a regressor in the extreme right column of Table 4 . The lag is highly significant and indeed the

15 It is also true that the monetary regime is chosen deliberately by the national authorities, so that the regime variables may be endogenous. We do not consider this to be an especially important issue since while the initial regime choice is endogenous, its duration is probably not affected much by simultaneity issues; no country chooses to adopt a monetary regime which it thinks will fail quickly. 
Table 4: Effect of Duration on Cumulative Success in the 0-4\% Band

\begin{tabular}{|c|c|c|c|c|c|c|}
\hline & $\begin{array}{l}\text { Default } \\
\text { sample }\end{array}$ & $\begin{array}{c}\text { Aggregate } \\
\text { measure } \\
\text { of } \\
\text { duration }\end{array}$ & World & $\begin{array}{c}\text { With } \\
\text { country } \\
\text { fixed effects }\end{array}$ & $\begin{array}{c}\text { With } \\
\text { country and } \\
\text { time fixed } \\
\text { effects }\end{array}$ & $\begin{array}{c}\text { With lagged } \\
\text { dependent } \\
\text { variable }\end{array}$ \\
\hline $\begin{array}{l}\text { Duration of } \\
\text { inflation } \\
\text { targeting }\end{array}$ & $\begin{array}{l}0.729^{*} \\
(0.039)\end{array}$ & & $\begin{array}{c}0.726^{* *} \\
(0.037)\end{array}$ & $\begin{array}{c}0.776^{* *} \\
(0.027)\end{array}$ & $\begin{array}{c}0.583^{* *} \\
(0.031)\end{array}$ & $\begin{array}{c}0.129^{* *} \\
(0.036)\end{array}$ \\
\hline $\begin{array}{l}\text { Duration of } \\
\text { fixed exchange } \\
\text { rate regimes }\end{array}$ & $\begin{array}{c}0.524 * * \\
(0.022)\end{array}$ & & $\begin{array}{c}0.343^{* *} \\
(0.012)\end{array}$ & $\begin{array}{c}0.559^{* *} \\
(0.017)\end{array}$ & $\begin{array}{c}0.462^{* *} \\
(0.019)\end{array}$ & $\begin{array}{c}0.079 * * \\
(0.027)\end{array}$ \\
\hline $\begin{array}{l}\text { Duration of } \\
\text { regimes without } \\
\text { an explicit } \\
\text { target }\end{array}$ & $\begin{array}{c}0.388^{* *} \\
(0.040)\end{array}$ & $(0.021)$ & $\begin{array}{c}0.311^{* *} \\
(0.030)\end{array}$ & $\begin{array}{c}0.349^{* *} \\
(0.019)\end{array}$ & $\begin{array}{c}0.316^{* *} \\
(0.019)\end{array}$ & $\begin{array}{l}0.044^{*} \\
(0.022)\end{array}$ \\
\hline $\begin{array}{l}\text { Duration of } \\
\text { money targeting } \\
\text { regimes }\end{array}$ & $\begin{array}{c}0.327 * * \\
(0.033)\end{array}$ & & $\begin{array}{c}0.311^{* *} \\
(0.029)\end{array}$ & $\begin{array}{c}0.229 * * \\
(0.019)\end{array}$ & $\begin{array}{c}0.242^{* *} \\
(0.019)\end{array}$ & $\begin{array}{l}0.047^{*} \\
(0.019)\end{array}$ \\
\hline $\begin{array}{l}\text { Lagged } \\
\text { dependent } \\
\text { variable }\end{array}$ & & & & & & $\begin{array}{c}0.939 * * \\
(0.049)\end{array}$ \\
\hline Observations & 1086 & 1086 & 3451 & 1086 & 1086 & 1017 \\
\hline R-squared & 0.59 & 0.51 & 0.49 & 0.63 & 0.68 & 0.94 \\
\hline
\end{tabular}

Coefficients reported (robust standard errors reported in parentheses. P-values less than .05 (.01) marked by one (two) asterisk(s). All regressions are estimated by OLS with intercept (not reported).

The dependent variable is based on the success of having inflation rate within $0 \%$ to $4 \%$ range. When inflation is in this range a binomial variable is set to 1 , otherwise it is zero. The dependent variable is the sum of the binomial success variable for each regime at every point in time.

Default sample: annual observations for 43 countries, 1974-2004.

"World" denotes all available observations.

magnitude of the coefficients on durations decline sharply. However, they remain highly significant for inflation targeting and also for fixed exchange rate regimes. ${ }^{16}$ The results thus suggest that success rate still increases significantly for fixed exchange rates and for inflation targeters with duration, even if we condition on lagged cumulative success.

Succinctly, the older any monetary regime is, the more likely it is to have delivered "good" inflationary outcomes (meaning inflation between $0 \%$ and $4 \%$ ). But not all regimes are created equal: inflation targeting is consistently associated with a higher likelihood of monetary success.

\section{Robustness Checks}

Are these results robust to reasonable variations in the specification? We show a variety of checks in Table 5 that show our key results are in fact relatively insensitive. In Panel 16 For money targeting and for regimes without an explicit target coefficient are significant only at the
$5 \%$ level. 
Table 5: Robustness Checks on the Effects of Duration on Cumulative Success

\begin{tabular}{lcc}
\hline & $\begin{array}{c}\text { Duration of } \\
\text { inflation targeting }\end{array}$ & $\begin{array}{c}\text { Duration of fix } \\
\text { exchange rate re }\end{array}$ \\
\hline \multicolumn{2}{c}{ A. With controls (0\%-4\% range) } \\
Default sample with & $0.928^{* *}$ & $0.737 * *$ \\
controls & $(0.052)$ & $(0.043)$ \\
World & $0.668^{* *}$ & $0.273^{* *}$ \\
& $(0.046)$ & $(0.028)$ \\
With country fixed & $0.984 * *$ & $0.721 * *$ \\
effects & $(0.046)$ & $(0.041)$ \\
With country and & $0.852 * *$ & $0.685 * *$ \\
time fixed effects & $(0.051)$ & $(0.040)$ \\
With lagged & $0.117 * *$ & $0.075 * *$ \\
dependent variable & $(0.033)$ & $(0.026)$
\end{tabular}

B. Success in the 1\%-3\% range

$\begin{array}{lcc}\begin{array}{l}\text { Default sample, no } \\ \text { controls }\end{array} & 0.500 * * & 0.320 * * \\ \text { Default sample with } & (0.038) & (0.022) \\ \text { controls } & 0.710 * * & 0.534 * * \\ \text { With controls, } & (0.045) & (0.039) \\ \text { country and time } & 0.609 * * & 0.493 * * \\ & (0.038) & (0.030)\end{array}$

C. Reinhart-Rogoff classification. Success in the 0\%-4\% range

$\begin{array}{lcc}\text { Default sample, no } & 0.745 * * & 0.550 * * \\ \text { controls } & (0.055) & (0.025) \\ \text { Default sample with } & 0.593 * * & 0.424 * * \\ \text { controls } & (0.070) & (0.046) \\ \text { With controls, } & 0.451 * * & 0.345 * * \\ \text { country and time } & (0.055) & (0.035)\end{array}$

fixed effects

D. Reinhart-Rogoff classification. Success in the $1 \%-3 \%$ range

$\begin{array}{lcc}\text { Default sample, no } & 0.513^{* *} & 0.331 * * \\ \text { controls } & (0.048) & (0.015) \\ \text { Default sample with } & 0.482^{* *} & 0.268^{* *} \\ \text { controls } & (0.055) & (0.028) \\ \text { With controls, } & 0.376^{* *} & 0.238^{* *} \\ \text { country and time } & (0.035) & (0.022) \\ \text { fixed effects } & & \end{array}$

Coefficients reported (robust standard errors reported in parentheses. P-values less than .05 (.01) marked by one (two) asterisk(s). All regressions are estimated by OLS with intercept (not reported).

The dependent variable is based on the success of having inflation rate within $(0,4 \%)$ or $(1,3 \%)$ range. When inflation is in this range a binomial variable is set to 1 , otherwise it is zero. The dependent variable is the sum of the binomial success variable for each regime at every point in time.

Default sample: annual observations for 43 countries, 1974-2004.

Controls: M2 growth, real GDP growth, terms of trade growth, openness, and the budget balance relative to GDP. "World" denotes all available observations. 
A we report results from the same regression as above, but now augmented with a set of five controls initially used by Husain et al (2005). The controls are: a) M2 growth, b) the growth rate of real GDP, c) the growth rate of the terms of trade, d) the budget balance relative to GDP and e) the degree of openness measured as imports plus exports divided by GDP. To conserve space we report only the coefficient estimates for the durations of inflation targeting and fixed exchange rate regimes (the two most important and common monetary regimes). A cursory look at the results suggests that the inclusion of controls does not change the estimates on durations significantly. For inflation targeting regimes, the effect of duration on success is almost equal to unity, i.e., each extra year of inflation targeting brings a year of achieving inflation within the range between $0 \%$ and $4 \%$, even after conditioning out other factors.

In panel $\mathrm{B}$ we show that switching to a more conservative range for the success variable also leaves our main conclusion intact; duration increases the success rate of achieving low inflation. To conserve space, we only report results for the default sample with and without controls and also with time and country fixed effects. Finally, panels $\mathrm{C}$ and $\mathrm{D}$ conduct the same set of exercises, but now for a data set in which fixed exchange rate regimes are determined by using the Reinhart and Rogoff (2004) classification. ${ }^{17}$

The results so far suggest clearly that duration and success are strongly correlated. We provide one more twist in the analysis of this relationship in Table 6. We construct a data set by extracting observations only at the end of each individual regime; thus, if the regime collapses, we use only the observation in the year immediately before the end of the regime. If the regime is still in place in 2004, then we use the data for 2004 as the final year of the regime. We are left with 236 regime-spells for our default sample (though we cannot use all of these sometimes, since some of the controls are missing). We divide the success rate by the overall regime duration to calculate the average rate of success. For example a country that had inflation within the $0 \%$ to $4 \%$ range in all years of its exchange rate targeting regime, will have a value for success equal to 1. A country that hit the low inflation range only half of the time will have success rate of 0.5 , etc.

The column at the extreme left suggests that both inflation targeting and fixed exchange rates are important explanatory variables for the average success in achieving low inflation. In this specification there is no worry about trending variables because we use the average success rate. The coefficient for inflation targeting implies that an extra year of IT raises the success rate by about four percentage points. Interestingly, duration does not explain average success in money targeting regimes or regimes without quantitative goals. These results confirm the suspicion of Table 4 that the duration coefficient for these two regimes was significant only because of common trends.

The remainder of Table 6 shows that the results are robust. For instance, similar results hold for a sample that includes all countries. The inclusion of controls in column 3 reduces the magnitude of the IT and ET coefficients somewhat relative to the bench-

17 Re-estimating all specifications from Table 4 or from Panel A of Table 5 by using the Reinhart-Rogoff classification produces highly significant coefficients on the variables capturing duration of inflation targeting and duration of fixed exchange rate regimes. 
Table 6: Effect of Duration on Average Success in the 0-4\% Range (evaluated at the end of the regime)

\begin{tabular}{|c|c|c|c|c|c|}
\hline & $\begin{array}{l}\text { Default } \\
\text { sample }\end{array}$ & World & $\begin{array}{c}\text { With } \\
\text { controls }\end{array}$ & $\begin{array}{l}\text { Aggregate } \\
\text { measure of } \\
\text { duration }\end{array}$ & $\begin{array}{c}\text { Aggregate } \\
\text { measure of } \\
\text { duration with } \\
\text { controls }\end{array}$ \\
\hline $\begin{array}{l}\text { Duration of } \\
\text { inflation } \\
\text { targeting }\end{array}$ & $\begin{array}{c}0.043 * * \\
(0.008)\end{array}$ & $\begin{array}{c}0.049^{* *} \\
(0.008)\end{array}$ & $\begin{array}{l}0.034 *- \\
(0.017)\end{array}$ & & \\
\hline $\begin{array}{l}\text { Duration of fixed } \\
\text { exchange rate } \\
\text { regimes }\end{array}$ & $\begin{array}{c}0.024 * * \\
(0.006)\end{array}$ & $\begin{array}{c}0.009^{* *} \\
(0.002)\end{array}$ & $\begin{array}{l}0.018^{*} \\
(0.008)\end{array}$ & & \\
\hline $\begin{array}{l}\text { Duration of } \\
\text { regimes without } \\
\text { an explicit target }\end{array}$ & $\begin{array}{c}-0.004 \\
(0.007)\end{array}$ & $\begin{array}{c}-0.003 \\
(0.004)\end{array}$ & $\begin{array}{c}-0.006 \\
(0.005)\end{array}$ & $\begin{array}{c}0.013^{* *} \\
(0.004)\end{array}$ & $\begin{array}{c}0.009 \\
(0.004)\end{array}$ \\
\hline $\begin{array}{l}\text { Duration of } \\
\text { money targeting } \\
\text { regimes }\end{array}$ & $\begin{array}{c}0.001 \\
(0.006)\end{array}$ & $\begin{array}{c}0.002 \\
(0.005)\end{array}$ & $\begin{array}{c}0.008 \\
(0.005)\end{array}$ & & \\
\hline Observations & 236 & 690 & 182 & 236 & 182 \\
\hline R-squared & 0.12 & 0.07 & 0.23 & 0.03 & 0.20 \\
\hline
\end{tabular}

Coefficients reported (robust standard errors reported in parentheses. P-values less than .05 (.01) marked by one (two) asterisk(s). All regressions are estimated by OLS with intercept (not reported).

The dependent variable is based on the success of having inflation rate within $0 \%$ to $4 \%$ range. When inflation is in this range a binomial variable is set to 1 , otherwise it is zero. The dependent variable is the sum of the binomial success variable for each regime at every point in time.

Default sample: annual observations for 43 countries, 1974-2004.

Controls: M2 growth, real GDP growth, terms of trade growth, openness, and the budget balance relative to GDP. "World" denotes all available observations.

mark, but they are still quite statistically significant. ${ }^{18}$ The final two columns report estimates for the duration of any regime.

\section{A Forecasting Approach}

Intrigued by the importance of durations in IT and ET regimes, we decided to explore further how well these regimes explain inflation. Instead of replicating the results in the literature, we continue to use our binary measure of monetary success (unity for inflation within the $0-4 \%$ band and zero otherwise). 19 However, instead of modeling cumulative success over time (as in Tables 4 and 5), we adopt a forecasting approach. In particular, we forecast the probability of successful monetary outcomes using a probit model. We ask: "Using data available today, can we predict the probability of achieving low inflation five years in the future?" This exercise includes the effects of

\footnotetext{
18 We use the same controls as in Table 4, but now they are calculated as averages over regimes.

19 The standard approach in the literature is to regress current inflation rate on current regime. See Fatás, Mihov and Rose (2007) and the review of the literature therein.
} 
both duration and the monetary regimes on inflationary outcomes. Using lagged regressors also mitigates the survivorship bias discussed before to a certain degree.

The specification for our forecasting model is the following:

$$
\operatorname{Prob}\left(\mathrm{S}_{\mathrm{it}}=1 \mid \text { data }\right)=\Phi\left(\alpha+\beta_{\mathrm{IT}} \mathrm{IT}_{\mathrm{i}, \mathrm{t}-5}+\beta_{\mathrm{E}} \mathrm{ERT}_{\mathrm{i}, \mathrm{t}-5}+\beta_{\mathrm{M}} \mathrm{MT}_{\mathrm{i}, \mathrm{t}-5}+\gamma^{\prime} \mathrm{X}_{\mathrm{i}, \mathrm{t}-5}\right)+\mathrm{u}_{\mathrm{it}}
$$

where:

- $S_{i t}$ is the binomial variable set to 1 when country $i$ has inflation rate between $0 \%$ and $4 \%$ at time $\mathrm{t}$.

- IT is a dummy for inflation targeting regimes, if one exists

- ERT is a dummy of fixed exchange rate regime, if one exists, using LYS 3-way classification

- $M T$ is a dummy of money targeting regime, if one exists

- $\quad \gamma$ is a set of nuisance coefficients

- $X$ is a vector of controls and/or fixed effects

We estimate this binary model with probit.

Our forecasting results are reported in Table 7. Without controls, all of the monetary regimes have a positive and significant effect on success rate at the 5-year horizon. It is worth pointing out that these coefficients capture the effect of each explicit regime relative to a "regime" without an explicit target. Hence the significance of the coefficients implies that all explicit targeting regimes raise the probability of success relative to regimes without explicit targets. The coefficient estimates can be used to calculate the marginal effect of each regime on the probability of inflationary "success." It turns out, that the marginal effect for inflation targeting, evaluated at the mean of the regressors is about 0.5 ; that is, an IT regime raises the probability of hitting the low-inflation range by about $50 \%$. This effect remains approximately the same for the whole sample, and for the specification with controls. The inclusion of time effects moderates the result somewhat bringing it down to $38 \%$. By way of comparison, the marginal effect of a fixed exchange rate regime is estimated in all cases to be about half the size of the IT effect. The increase in the probability of success for fixed exchange rate regimes ranges from a low of $13 \%$ (in the specification for the whole world) to a high of $23 \%$ (in the specification for the default sample without controls). Similarly, money targeting is significant from a statistical point of view, but the effect is only about one third of the IT effect. ${ }^{20}$

To summarize, while a fixed exchange rate regime raises the odds of low future inflation, inflation targeting raises the chances much more.

20 Extending the forecasting horizon to 7 years has no noticeable effect on our results. On the other hand bringing down the forecasting horizon to only 3 years reduces substantially the marginal effect of all regimes, and in some specification makes the coefficient on fixed exchange rate regimes insignificant. 
Table 7: Forecasting the Probability of Success in the 0-4\% Range at 5-Year Horizon

\begin{tabular}{|c|c|c|c|c|c|}
\hline & $\begin{array}{l}\text { Default } \\
\text { sample }\end{array}$ & World & $\begin{array}{l}\text { With time } \\
\text { fixed effects }\end{array}$ & $\begin{array}{c}\text { With } \\
\text { controls }\end{array}$ & $\begin{array}{l}\text { With controls } \\
\text { and time fixed } \\
\text { effects }\end{array}$ \\
\hline $\begin{array}{l}\text { Dummy for } \\
\text { inflation } \\
\text { targeting (lagged } \\
5 \text { years) }\end{array}$ & $\begin{array}{l}1.529 * * \\
(0.184)\end{array}$ & $\begin{array}{l}1.682 * * \\
(0.177)\end{array}$ & $\begin{array}{l}1.002 * * \\
(0.198)\end{array}$ & $\begin{array}{l}1.529 * * \\
(0.188)\end{array}$ & $\begin{array}{c}1.008 * * \\
(0.202)\end{array}$ \\
\hline $\begin{array}{l}\text { Dummy for fixed } \\
\text { exchange rate } \\
\text { regimes (lagged } 5 \\
\text { years) }\end{array}$ & $\begin{array}{c}0.603 * * \\
(0.104)\end{array}$ & $\begin{array}{c}0.385 * * \\
(0.062)\end{array}$ & $\begin{array}{c}0.550 * * \\
(0.111)\end{array}$ & $\begin{array}{c}0.479 * * \\
(0.114)\end{array}$ & $\begin{array}{c}0.413 * * \\
(0.122)\end{array}$ \\
\hline $\begin{array}{l}\text { Dummy for } \\
\text { money targeting } \\
\text { regimes (lagged } 5 \\
\text { years) }\end{array}$ & $\begin{array}{c}0.425 * * \\
(0.122)\end{array}$ & $\begin{array}{l}0.395 * * \\
(0.102)\end{array}$ & $\begin{array}{c}0.450 * * \\
(0.130)\end{array}$ & $\begin{array}{c}0.485 * * \\
(0.128)\end{array}$ & $\begin{array}{c}0.472 * * \\
(0.138)\end{array}$ \\
\hline Observations & 876 & 2783 & 849 & 822 & 772 \\
\hline
\end{tabular}

Coefficients reported (robust standard errors reported in parentheses. P-values less than .05 (.01) marked by one (two) asterisk(s). All regressions are estimated by OLS with intercept (not reported).

The dependent variable is a binomial variable based on the success of having inflation rate within $0 \%$ to $4 \%$ range. When inflation is in this range a binomial variable is set to 1 , otherwise it is zero.

Default sample: annual observations for 43 countries, 1974-2004.

Controls: M2 growth, real GDP growth, terms of trade growth, openness, and the budget balance relative to GDP. "World" denotes all available observations.

\section{Conclusion}

There is so much art in the world that nobody can experience it all. (The same can be said for movies, music, and much else.) So you have to choose; how? Time is a simple and remarkably good filter; it is rare to see poor 200-year old art. In this paper, we assess monetary regimes using the filter of time.

Inflation targeting seems like it would be a monetary regime that would compare poorly using the filter of time. After all, IT is a relatively new monetary regime. Nevertheless, we have found that IT seems already to have withstood the test of time; the duration of IT regimes is already as long as or significantly longer than alternatives like fixed exchange rates. Unlike all other monetary frameworks, no country has yet been forced to abandon a regime of inflation targeting in crisis. And this duration matters, since more durable monetary regime are systematically associated with better inflationary outcomes, meaning inflation within a band of $(0,4 \%)$. While having an exchange rate fix is better than having no clear quantitative target for monetary policy, inflation targeting is more likely to be associated with good inflationary outcomes.

Any extrapolation of the heretofore successful record of inflation targeting remains exactly that: an extrapolation. Still, IT seems to work in both theory and practice, and is spreading quickly. Most importantly, inflation targeting is developing a reputation for durability, something that cannot be said of many alternative monetary regimes. Perhaps the monetary mishaps of the past will soon be seen as the byproduct of antiquated monetary regimes. 


\section{Appendix}

Table A1: Tests of Final Monetary Regime Duration: Inflation Targeting vs. Fixed Exchange Rates

\begin{tabular}{|l|c|}
\hline Alternate Monetary Regime & \\
\hline GGW, 1999 & $3.1^{* *}$ \\
\hline RR, 2001 & $2.2^{*}$ \\
\hline LYS-5, 2004 & -.4 \\
\hline BOR, 2003 & $2.3^{*}$ \\
\hline SB, 2005 & .1 \\
\hline
\end{tabular}

Statistics tabulated are z-statistics from two-sample Wilcoxon rank-sum (Mann-Whitney) tests comparing durations of final monetary regime with Inflation Targeting regimes. Positive statistic indicates IT has longer duration than alternative. P-value less than .05 (.01) marked by one (two) asterisk(s).

GGW: De jure exchange rate regime from Ghosh, Gulde, and Wolf (2003). RR: De facto exchange rate regime from Reinhart and Rogoff (2004). LYS-5: De facto 5-way exchange rate regime from LevyYeyati and Sturzenegger (2005). BOR: De facto regime from Bubula and Otker-Robe (2002). SB: De facto regime from Stone and Bhundia (2004). Default sample of countries and years.

Table A2: Effect of duration on Cumulative Success in the 0-4\% Band.

Estimation by Poisson Regression.

\begin{tabular}{|c|c|c|c|c|c|c|}
\hline & $\begin{array}{l}\text { Default } \\
\text { sample }\end{array}$ & $\begin{array}{c}\text { Aggregate } \\
\text { measure of } \\
\text { duration }\end{array}$ & World & $\begin{array}{c}\text { With } \\
\text { country } \\
\text { fixed effects }\end{array}$ & $\begin{array}{c}\text { With } \\
\text { country } \\
\text { and time } \\
\text { fixed effects }\end{array}$ & $\begin{array}{c}\text { With } \\
\text { lagged } \\
\text { dependent } \\
\text { variable }\end{array}$ \\
\hline $\begin{array}{l}\text { Duration of } \\
\text { inflation } \\
\text { targeting }\end{array}$ & $\begin{array}{c}0.234 * * \\
(0.006)\end{array}$ & & $\begin{array}{c}0.256 * * \\
(0.005)\end{array}$ & $\begin{array}{c}0.280 * * \\
(0.011)\end{array}$ & $\begin{array}{c}0.201 * * \\
(0.015)\end{array}$ & $\begin{array}{c}0.047 * * \\
(0.008)\end{array}$ \\
\hline $\begin{array}{l}\text { Duration of fixed } \\
\text { exchange rate } \\
\text { regimes }\end{array}$ & $\begin{array}{c}0.148 * * \\
(0.003)\end{array}$ & & $\begin{array}{c}0.121 * * \\
(0.001)\end{array}$ & $\begin{array}{c}0.179 * * \\
(0.007)\end{array}$ & $\begin{array}{c}0.119 * * \\
(0.010)\end{array}$ & $\begin{array}{l}0.013 * \\
(0.005)\end{array}$ \\
\hline $\begin{array}{l}\text { Duration of } \\
\text { regimes without } \\
\text { an explicit target }\end{array}$ & $\begin{array}{c}0.119 * * \\
(0.003)\end{array}$ & $(0.003)$ & $\begin{array}{c}0.123 * * \\
(0.003)\end{array}$ & $\begin{array}{c}0.092 * * \\
(0.008)\end{array}$ & $\begin{array}{c}0.028 * * \\
(0.010)\end{array}$ & $\begin{array}{c}-0.021 * * \\
(0.005)\end{array}$ \\
\hline $\begin{array}{l}\text { Duration of } \\
\text { money targeting } \\
\text { regimes }\end{array}$ & $\begin{array}{c}0.125 * * \\
(0.005)\end{array}$ & & $\begin{array}{c}0.136 * * \\
(0.004)\end{array}$ & $\begin{array}{c}0.076 * * \\
(0.007)\end{array}$ & $\begin{array}{c}0.047 * * \\
(0.007)\end{array}$ & $\begin{array}{c}0.019 * * \\
(0.006)\end{array}$ \\
\hline $\begin{array}{l}\text { Lagged } \\
\text { dependent } \\
\text { variable }\end{array}$ & & & & & & $\begin{array}{c}0.226 * * \\
(0.008)\end{array}$ \\
\hline Observations & 1086 & 1086 & 3451 & 960 & 960 & 1017 \\
\hline
\end{tabular}

Coefficients reported (standard errors reported in parentheses). P-values less than .05 (.01) marked by one (two) asterisk(s). All regressions are estimated by a Poisson regression.

The dependent variable is based on the success of having inflation rate within $0 \%$ to $4 \%$ range. When inflation is in this range a binomial variable is set to 1 , otherwise it is zero. The dependent variable is the sum of the binomial success variable for each regime at every point in time.

Default sample: annual observations for 43 countries, 1974-2004.

"World" denotes all available observations. 


\section{References}

Ball, Laurence, and Niamh Sheridan (2004) "Does Inflation Targeting Matter?" in The Inflation-Targeting Debate (Bernanke and Woodford, eds): Chicago, University Press.

Bernanke, Ben S., and Frederic S. Mishkin (1997) "Inflation Targeting: A New Framework for Monetary Policy?" NBER Working Paper No 5893.

Bubula, Andrea, and Ínci and Otker-Robe (2002) "The Evolution of Exchange Rate Regimes since 1990" IMF Working Paper 02/155.

Cottarelli, Carlo, and Curzio Giannini (1997) “Credibility Without Rules?” IMF Occasional Paper 154.

Ghosh, Atish, Anne-Marie Gulde and Holger C. Wolf (2003) Exchange Rate Regimes: Choices and Consequences (Cambridge: MIT Press).

Dehejia, Vivek H., and Nicholas Rowe (2000) “Macroeconomic Stabilisation”, unpublished.

Dueker, Michael J., and Andreas M. Fischer (2006) "Do Inflation Targeters Outperform NonTargeters?" Federal Reserve Bank of St. Louis Review 431-450.

Fatás, Antonio, Ilian Mihov and Andrew K. Rose (2007) "Quantitative Goals for Monetary Policy," Journal of Money, Credit and Banking, August.

Husain, Aasim, Ashoka Mody, and Kenneth S. Rogoff (2005) "Exchange Rate Regime Durability and Performance in Developing versus Advanced Economies" Journal of Monetary Economics 52:1, 35-64.

IMF (various years) Annual Report on Exchange Arrangements and Exchange Restrictions.

Klein, Michael, and Nancy Marion (1997) "Explaining the Duration of Exchange-Rate Pegs" Journal of Development Economics 54, 387-404.

Levy-Yeyati, Eduardo, and Federico Sturzenegger (2005) "Classifying Exchange Rate Regimes" European Economic Review 49, 1603-1635.

Mishkin, Frederic S. (1998) "International Experiences with Different Monetary Policy Regimes" IIES Seminar Paper No. 648.

Mishkin, Frederic S., 2004. Can Inflation Targeting Work in Emerging Market Countries? NBER Working Paper No. 10,646, Cambridge MA.

Mishkin, Frederic S., and Klaus Schmidt-Hebbel (2001) "One Decade of Inflation Targeting in the World: What do we Know and What do we Need to Know?" NBER Working Paper No. 8397.

Reinhart, Carmen M., and Kenneth S. Rogoff (2004) "The Modern History of Exchange Rate Arrangements" Quarterly Journal of Economics 119(1), pages 1-48.

Roger, Scott, and Mark Stone (2005) "On Target? The International Experience with Achieving Inflation Targets" IMF Working Paper WP/05/163.

Rose, Andrew K. (2000) “One Money, One Market” Economic Policy 30, 7-45.

Rose, Andrew K. (2006) "A Stable International Monetary System Emerges: Inflation Targeting is Bretton Woods, Reversed" NBER Working Paper 12,111.

Stone, Mark R., and Ashok J. Bhundia (2004) “A New Taxonomy of Monetary Regimes" IMF Working Paper 04/191. 
Svensson, Lars E. O. (1999) "Inflation Targeting as a Monetary Policy Rule" Journal of Monetary Economics 43(3), 607-654.

Vega, Marco, and Diego Winkelried (2005) "Inflation Targeting and Inflation Behavior: A Successful Story?" International Journal of Central Banking, 153-175.

Wälti, Sébastien (2005) “The duration of fixed exchange rate regimes" unpublished. 
Please note:

You are most sincerely encouraged to participate in the open assessment of this article. You can do so by either rating the article on a scale from 5 (excellent) to 1 (bad) or by posting your comments.

Please go to:

www.economics-ejournal.org/economics/journalarticles/2008-13

The Editor 